\title{
Friedrich Avemarie, Predrag Bukovec, Stefan Krauter, Michael Tilly (eds.), Die Makkabäer (Wissenschaftliche Untersuchungen zum Neuen Testament - 382), Mohr Siebeck, Tübingen 2017, 471 pp., ISBN 978-3-16-153861-2
}

The extensive legacy of ancient Jewish literature contains as many as five works whose title refers to the name of the Maccabees. Four of these are well known to scholars. Major doubts surround the originality of the fifth, as well as the title ascribed to it. Most scholarly attention is paid to the first two books, owing to their significance as the main historical sources describing the Maccabean Revolt, while the other two arouse considerably less interest as their content has little to do with the events that took place in Judaea. It was therefore a commendable idea to examine all the works with the term "Maccabee" in the title, which served as the inspiration for the organisers of an academic conference that took place in Tübingen between 30 May and 2 June 2013. The papers presented at the conference have now been published in the volume Die Makkabäer, suggesting that the book's main focus is Maccabean history. Although this subject is indeed present, the articles included concern a wide array of issues going beyond purely historical themes. The volume contains articles on historical-literary issues, historical events, social history and history of religion, as well as the general reception of the Books of Maccabees.

The largest group of articles are those focusing on analysis and interpretation of 1 Maccabees or referring to its message (A. Lichtenberger, "Die Jerusalemer Religionsreform im Kontext. Antiochos IV., Antiochia und Zeus Olympios," pp. 1-20; H. Lichtenberger, "Die Qumrantexte als Quelle für die Makkabäerzeit," pp. 21-40; A. Klostergaard Petersen, "1 Maccabees from an Axial Age Perspective," pp. 41-67; D. R. Schwartz, "1 Maccabees 14 and the History of the Hasmonean State," pp. 69-84). Particularly noteworthy is D. R. Schwartz's text devoted to the problem of legitimation of the rule of Simon and John Hyrcanus. The author analyses a passage from 1 Macc (14: 25-49), arguing that is essential for forming an understanding of this question. The conclusions stemming from the analysis of this passage demonstrate a major difference in the formal positions of Simon and John Hyrcanus. Important for the legality of Simon's tenure of the office of high priest was the formal consent of King Demetrius II, while in the case of John Hyrcanus it was the argument that he possessed prophetic abilities (pp. 72-83). A separate group of articles is those concerning selected issues discussed by the author of 2 Maccabees (J. W. van Henten, "Time as a Narrative Tool in 2 Maccabees," pp. 85-106; B. Ego, "Der Tempel im 2. Makkabäebuch im Kontext der Jerusalemer Kultkonzeption,” pp. 107-121; M. Öhler, “Judäer oder Juden? Die Debatte ,Ethnos vs. Religion“ im Blick auf das 2. Makkabäerbüchern,” pp. 157-185; L. Neubert, "Inventing 
Jason of Cyrene? 2 Maccabees and the Epitome,” pp. 187-208), while the authors of several others analyse questions reflected in 1 and 2 Maccabees (A. Lange, "Jeremia in den Makkabäerbüchern," pp. 209-219; J. C. Bernhardt, "Judas und seine Brüder. Zum Bild der Hasmonäerfamilie in den Makkabäerbüchern," pp. 221-243; G. S. Oegema, "1 and 2 Maccabees in Paul's Letter to the Galatians," pp. 345-360), or use the references in both books to depict the issue of the religious life of the Jewish diaspora (C. Leonhard, "Tempelfeste außerhalb des Jeruslemer Tempels in der Diaspora," pp. 123-155). Worth mentioning among this group of articles is J. C. Bernhardt's paper describing the differing portrayal of Judah Maccabee and his brothers provided by the two books. Despite the undoubted pro-Hasmonean sympathies of the authors of 1 and 2 Maccabees and their attempts to depict the harmonious cooperation of the sons of Mattathias at the time of the revolt, a number of details can be discerned in their accounts that lead to the conclusion that this is a distorted image. In the case of 1 Macc, there is no doubt that the author distinctly overstates Simon's actions at the cost of his brothers. It is also worth noting that Bernhardt's and D. R. Schwartz's articles are complementary.

The history of research on 3 Maccabees from the second half of the sixteenth century until the beginning of the twentieth century is the subject of T. Köppler's article ("Marksteine der wissenschaftlichen Arbeit am 3. Makkabäerbuch (1564-1913)," pp. 427-448), incidentally the only text in the book to focus on this work. The conference participants paid somewhat more attention to 4 Maccabees, and related subjects are addressed in three articles (A. M. Schwemer, "Zur Entstehungszeit und -ort des 4. Makkabäerbuchs," pp. 245-274; P. Bukovec, "Per aspera ad astra. Leben nach dem To dim 4. Makabäerbüch,” pp. 275-303; J. Dochhorn, “,Ich bewahrte die gebaute Seite“ (4 Makk 18,7). Eine Referenz auf die Verführung der ersten Frau im vierten Makkabäerbuch und ihre überliefungsgeschichtlichen Hintergründe," pp. 305-326). Among these, A. M. Schwemer's article will certainly be of interest to many readers. The author discusses the time and place of origin of 4 Maccabees, concluding that it was written in Antioch in the 30s CE (p. 270).

The final group consists of three articles concerning the forms of reception and influence of Maccabean tradition on Christian tradition (D. Richter, "Die Geschichte vom Martyrium der Sieben Brüder (2 Makk 7) in der westlichen Tradition," pp. 361-377), rabbinical tradition and contemporary Judaism (M. Morgenstern, ",Gendered Restistance'. Anmerkungen zur Makkabäer-Rezeption im rabbinischen und modernen Judentum," pp. 379-401). A slightly different form of influence of Maccabean tradition is the focus of the third article, which concerns the position towards Jewish and Greek culture of the German philosopher Hermann Cohen (1842-1918). Since Cohen did not present his views systematically, the author attempts to reconstruct them on the basis of his works. He is a particularly interesting figure as the formation of his views was affected by the ideology of the times in which he lived as well as his identity as a philosopher (H. P. Lichtenberger, "Judentum und Griechentum bei Hermann Cohen," pp. 403-425). S. Krauter's article ("Tacitus über Antiochos IV. und die Makkabäer," pp. 327-343) on Tacitus' brief excursus on Antiochus IV and the Jews (Hist. 5.8.2-3) merits a separate mention. In it, the Roman historian expressed his unequivocally unfavourable attitude towards the inhabitants of Judaea. The author rules out the possibility that its contents might have been borrowed from any source (p. 329). In his opinion, this excursus contains a reflection of the Flavian anti-Jewish political propaganda slogans. The reference 
to Antiochus IV's position on the Maccabean Revolt was intended to justify the Roman stance towards the Jews and Titus' need to destroy the Jerusalem temple (p. 341).

The diversity of the problems analysed in the various articles means that this book will certainly find a wide readership. Without doubt, the large number of articles on 1 and 2 Maccabees means that it will be especially popular among scholars with an interest in these works as literary products and in their reception, as well as those researching the Maccabean Revolt and Hasmonean rule.

Edward Dąbrowa (Jagiellonian University in Kraków) 